\title{
MODERN CONSUMER IN CYBERSPACE - INTERNET AND PSYCHOLOGY APPROACH
}

\author{
Marta R. JABŁOŃSKA
}

University of Lodz, Faculty of Economics and Sociology

Institute of Applied Economics and Informatics, Lodz, Poland

e-mail: mjablonska@uni.lodz.pl

\begin{abstract}
Online reality becomes a natural environment for nowadays companies. As more and more companies have understand a necessity of their presence in the cyberspace, they still need to learn about complex nature of young people who are becoming customers. The paper aims to present modern consumer from sociological and psychological perspective. First, it describes generations $\mathrm{Y}, \mathrm{Z}$, and $\mathrm{C}$ and their most common online activities and then concentrates on their behaviors performed online. To reach the aim of the paper, a study has also been conducted to investigate discussed behaviors.
\end{abstract}

Keywords: digital natives, internet psychology, customer behavior, social media.

\section{Introduction}

Nowadays, society is becoming increasingly complex (Qvortrup, 2003) and that implicates living up against ever-present change in almost every aspect of human or business life. Thanks to the Internet and the spread of Web 2.0 services, a significant change in the public space and social context emerges and influences whole communities as well as single individuals (Nowak and Krejtz, 2006). This applies also to the customers and their everyday online behaviors.

The beginning of the 21st century has brought forth a massive widespread of Web 2.0 services. The term itself was coined more than 10 years ago by Tim O'Reilly in his memorable paper (2005). Traditionally, the Internet has been perceived and applied as a one-way communication channel but Web 2.0 refers to open and participatory work (Rakshikar, 2015). The concept has become even more popular because of the advent of social networking, enabling easy multiway communication among users (Tennant, et al., 2015).

As a result, Web 2.0 contributed considerably to the creation of numerous, diversified in nature, active online communities. Every user may easily not only access but also cocreate online content. It is a great opportunity of Web 2.0 and also one of its biggest threats. On the one hand, interesting content can become viral, which means that it spreads over the Internet quickly, gathering numerous Web communities excited by presented information.
Yet, on the other hand, the quality of produced content may become lower and Internet users have to face an information overload. Among other disadvantages attributed to Web 2.0 and social networking, the time-consuming effort it took to learn how to use them in an effective manner or prepare highquality, persuasive content should be mentioned (Dooley, Jones and Iverson, 2014).

Nowadays, companies need to stand out from this online information overload and realize that social media changed customer purchasing behaviors. That is why business has to face the necessity of creating diversified and customer-appealing Internet content strategy. To reach this aim, companies need to learn and understand about consumers spending most of their time in the cyberspace, their behaviors, interests, purchase motivations, and desires. Then it is necessary to realize that social media may be new and promising way to reach them and gain their attention. Properly designed online content marketing strategy may help to establish a wide audience, devoted followers, or even brand advocates (Leibtag, 2013).

Owing to Marc Prensky (2001), Web users may be divided into two groups: digital immigrants and digital natives. People who are aware of Internet technologies and even use them every day but were born in times preceding Web 2.0 widespread deployment are called digital immigrants. They encountered Internet at some stage of life and, disregarding their level of fluency in these technologies, cyberspace will remain separate part of their dailiness, not on 
a par with real life. As an immigrant may learn foreign language, this cohort of people may adopt Internet technologies but they usually remain outsiders, possessing an "accent" emphasizing the fact that full assimilation in the new digital space is impossible. Conversely, digital natives were born in times of being "always online," when they experience Internet dynamic dissemination in almost every aspect of their life. They do not know the world without the Internet, and they can't imagine it, as their immersion in virtual reality takes the strongest form, resulting often in treating real and virtual space as one and the same. To separate digital immigrants from natives, Prensky had set 1980 as a border date (immigrants were born before and natives after).

This article concentrates on the most Internet heavy users - digital natives. Young people are also classified as representatives of generations $\mathrm{Y}$ and Z. Generation $\mathrm{Y}$, also known as the "Me, me, me," "wired," "net" generation, or simply "Millenials," lives various spheres of everyday reality in the cyberspace. They work, educate, entertain, communicate, socialize, and shop online. Generation $\mathrm{Z}$ remains still in their teens, yet they are starting to participate in market as consumers with their first purchase behaviors. They are growing up in times of dynamic dissemination of the Internet and mobile technologies. A world without the Internet can be seen as an abstraction as the Web has existed for them "from always." They are very fluent and highly immersed in cyberspace more and more often at the expense of real life. Generation $\mathrm{Z}$ representatives perceive online reality as equally important as the real one and put a strong emphasis on the creation of their own e-personality.

Above characterization, it presents a brand new type of a customer. The paper aims to present it and describe online behavior patterns that may be useful for companies to understand the nature of their nowadays and future online customers. To reach this goal, a study concerning performed online activities among generations $\mathrm{Y}$ and $\mathrm{Z}$ representatives was conducted. The remainder of the paper is organized as follows. Section 2 briefly presents young people classification as representatives of generations $\mathrm{Y}, \mathrm{Z}$, and $\mathrm{C}$ as well as reveals most common online behaviors typical for these cohorts. Section 3 is dedicated to an explanation of methodology and construction of the study. Findings, conclusions, and future works are given in Sections 4 and 5, respectively.

\section{Nowadays and future consumer - demographic and psychological approaches}

This section provides a description of digital natives from demographical and psychological points of view. The first perspective seeks characteristics of generations $\mathrm{Y}, \mathrm{Z}$, and $\mathrm{C}$. The second concentrates on behaviors evinced by this cohort of consumers on the Web. Each of these generations will be characterized by increasing immersion into cyberspace. The Internet not only will constitute desirable and necessary working tool but also will be absorbing consecutive activities of everyday life. Almost every aspect of life - such as education, work, hobbies, entertainment, TV, press, radio, shopping, contact with administration and authorities, payments, searching for information, religion, acquaintances, socialization, and even relationships - seems to be marked with online reality. Such ubiquitous Internet interaction on young people's mind and personality can't remain without affecting their everyday living, personal development, and the perception of other people, society, and environment.

\subsection{Demographic perspective}

The name of first generation, Millenials (also called "Y," "net," "wired," "echo boom," "Me, me, me," or iGeneration), refers to the millennium, although the scope of the dates of birth is still debated. The term "generation Y" has adopted virtually all over the world, but depending on the cultural background, national prosperity, and computerization of society, different countries take divergent date ranges. For example, the United Kingdom and the United States define them as people born in the years 1980-1990, while Australia greatly expands the range for the years 1983-2000. One of the Polish studies suggests period from 1977 to 1997 (Dejnaka, 2013). Generally speaking, the representatives of generation $\mathrm{Y}$ may be perceived as people born at the beginning of the 1980s to the end of the last century. 


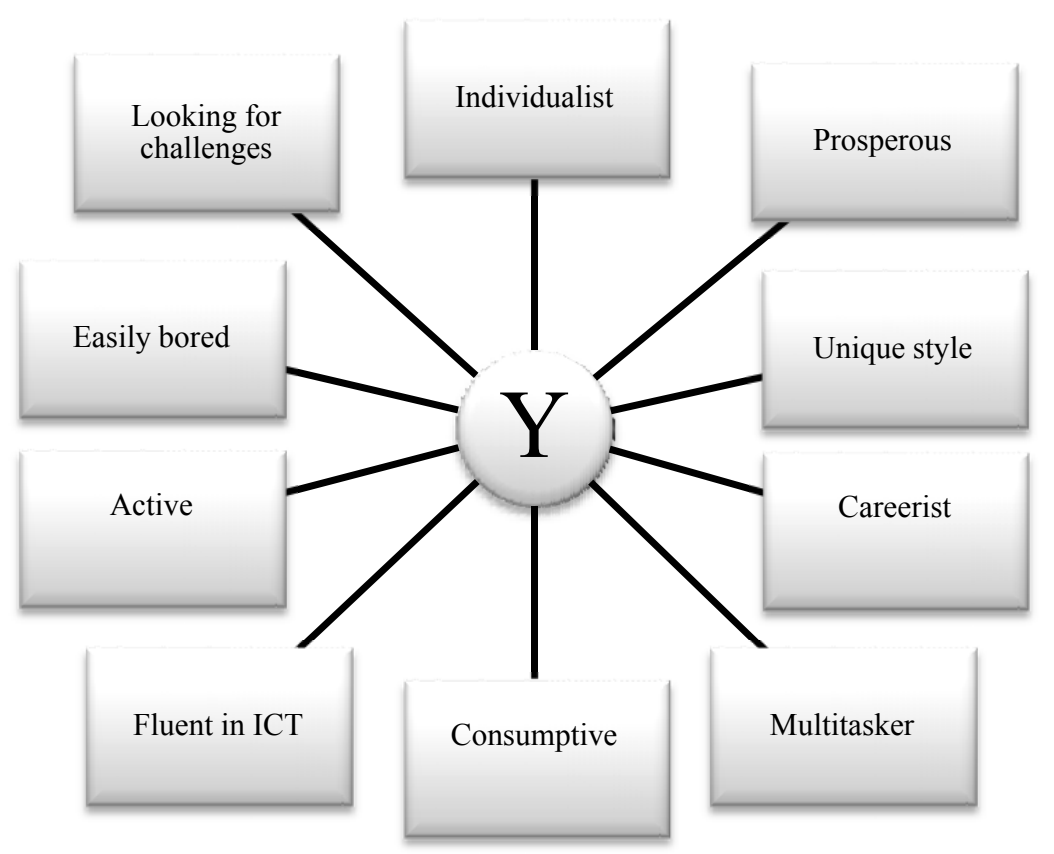

Figure 1. Generation Y's profile (source: own elaboration)

Generation Y's representatives may be characterized by several features presented in Fig. 1.

One of the most important features in fluency in information and communications technology (ICT) and Internet technologies. For generation Y, online reality is important and used daily. What is more, they are aware of the influence of Internet on their life and everyday activities (Nielsen Report, 2014). They operate in two worlds, real and virtual one, but still are able to distinguish these two realities.

Generation Y's representatives as customers can be quite loyal. According to research conducted recently by Facebook, $77 \%$ of respondents still hark back to the same brands, $37 \%$ indicated themselves as loyal to the brand, and $40 \%$ declared repeatable purchases but without allegiance to a particular brand. Among factors influencing Millenials' loyalty, following can be mentioned: price, convenience, trust, customer service, and unique experience with a brand. This study also proven that Millenials willing to use Facebook and Instagram regularly are more likely to be loyal to brands. (Facebook IQ, 2016).

Personality traits and attitudes characteristic for generation $\mathrm{Y}$ will also be present in characteristic of next generation, although some of them will be gradually muted, while others will be significantly gaining momentum. Generation following the $\mathrm{Y}$ is the generation $\mathrm{Z}$. Born in the beginning of this century, they are young people, some just entering adulthood.

Generation Z's representatives are growing up in a world in which, on the one hand, the Internet and online reality are ubiquitous, social media that breaks records of popularity and brand competing in reaching out to customers through all channels, but, on the other hand, these young people are witnessing a growing cyber and terrorist attacks. Like the previous generation, modern technologies have a strong impact on their daily activities.

They are similar to their predecessors: posses an outstanding ease of assimilation of modern technologies, spend more and more time on the Internet or social media, thereby increasing their ability to multitask and divide attention, expect fast gratification, and are not especially patient. For the majority of representatives of the generation $\mathrm{Z}$, the Internet has existed "forever." Unlike Millenials, generation $\mathrm{Z}$ not only intensively move to cyberspace further aspects of everyday life but also increasingly become immersed in the virtual world. Immersion in cyberspace becomes so strong that virtual reality becomes 
as significant as the real one or sometimes even more important.

About $65 \%$ of the representatives of another generation is under 35. Still, age is not a criterion for becoming a member of this cohort. Generation $\mathrm{C}$ is all about lifestyle as the letter "C" to connection, community, creation, curators, content-centric, computerized, always clicking, control, celebrity, and so on. These are people who spend a lot of time in cyberspace, creating and evaluating the published content, living in virtual communities in which they wish to create their unique, interesting image. Typical generation C's representative can be characterized as follows:

- values integrity and internal cohesion,

- perceived as a materialist and realist,

- creative,

- liberal, though not necessarily in the political dimension of the term,

- uses and relies on modern technologies,

- stays online 24 hours, 7 days a week,

- hedonist,

- prefers the Internet over the traditional media such as television, radio, or the printed press,

- socializes, works, learns, purchases online, lives in a virtual community, without geographical limitations,

- constantly uses smartphone,

- participates in the life of many different communities in cyberspace at the same time,

- has many online acquaintances,

- creates and publishes content and likes to share it,

- more inclined to mobility, but, at the same time, lives with parents until quite a late age,

- processes huge amounts of information on the Internet, but generally very superficially,

- prefers to communicate through the screen than face to face.

- reduces the level of privacy on the Internet by posting statuses, locations, data, friends, interests, shopping, and so on (Kaplan, 2015).

All of the above generations are interesting field of study for various researches dedicated to their online behaviors and purchases over the Internet.
While analyzing current literature, following areas of investigation may be mentioned. Mitchell et al. (2015) described generation Y's Internet ethical attitudes, while Lee and Cook (2014) investigated this generation experiences of Internet surveillance.

The sociodemographic profile of generation $\mathrm{Y}$ online shoppers and their online shopping behaviors was analyzed by research teams from various countries, including Taiwan (Lai and Liang, 2009), Malaysia (Muda, Mohd and Hassan, 2016), Poland (Jabłońska and Billewicz, 2016), Romania (Dabija, Babut and Lugojan, 2016), Indonesia (Simanjuntak and Musyifah, 2016), Bangladesh (Rahman, 2015), and the United States (Seo, 2016). Smutny, Janoščík, and Čermák (2016) focused on social networking and Millenials' attitudes to privacy from a technological, social, generational, cultural, and philosophical points of view.

Some papers concentrated on the comparisons between generations, for example, Lissitsa and Kol (2016) wrote about $\mathrm{X}$ and $\mathrm{Y}$ online shopping habits and Dhanapal, Vashu, and Subramaniam (2015) focused on Baby Boomers, generation $\mathrm{X}$, and generation $\mathrm{Y}$ points of view on the challenges of online purchasing. Fletcher (2016) presented a chapter dedicated to generation Y's social media engagement, while Hassan and Shailesh (2016) wrote about enhancing Millenials' connectivity through instant messaging usage.

There were also works dedicated to Generation Y's online Web site satisfaction (Lim, et al., 2016), attitudes toward online shopping (Makhitha, 2014), the relationship between subjective norm, perceived usefulness, and online shopping behavior while mediated by generation Y's purchase intention (Lim, et. al., 2015).

Among papers dedicated to generation Z, Shin, Fowler, and Lee (2013) provided insight into current social media influences and purchasing power; Greydanus and Greydanus (2012) described excessive Internet use among generation Z's representatives; Escoda, Zubizarreta, and Higado (2016) investigated this cohort's digital skills; and Ozkan and Solmaz (2015) focused on their online social life. Hulten (2015) discussed social media and its significance in the dialogue between both businesses and consumers. 
Zhitomirsky-Geffet and Blau (2016) conducted an analysis of smartphone usage among representatives of generations $\mathrm{X}, \mathrm{Y}$, and $\mathrm{Z}$. It is important to realize that - in comparison to generation $\mathrm{Y}-$ studies about generation Z's representatives are limited by their age - remaining in their teens, the oldest are only coming of age now.

Ferguson and Geer (2016) studied the usage of digital tools to connect with generation C, and Kaplan (2015) described marketing strategies for the generation $\mathrm{C}$ consumer behavior.

\subsection{Psychological perspective}

All of the described generations have a feature in common: they shuffle another aspects of everyday life online. As a result, a massive part of their daily activities is performed online. The important fact is that some people do not act in cyberspace the same as in real life, so they can write and do things online that they wouldn't normally perform in face-to-face communication. This phenomenon is called disinhibition effect (Suler, 2004). These changes are crucial for psychologists and sociologists and also they may be an important factor of understanding online behaviors of nowadays customer.

As described in previous section, nowadays generations want to be seen as individuals with unique style and experience. The Internet, especially social media, concentrates on people and their digital image. Web users may perform multiple roles, create new facts about their lives, and share them with broad audience.

The Internet offers almost limitless possibilities for self-promotion. Likes and positive comments on social media profiles improve mood, increase self-esteem, allow to look at yourself more favorably. That is why cyberspace may be perceived as a factor escalating narcissistic tendencies. According to Stein (2013), the incidence of narcissistic personality disorder is nearly three times as high for young people as for older "offline" generations and more than a half of college students scored higher on a narcissism scale in 2009 than in 27 years before.

The Internet also escalates some aspects of nowadays life: increasing pace of life, globalization, rising body cult and significance of external status symbols that indicate one's success, expanding number of brief, short-term relationships started and maintained only online, decreasing role in the cyberspace human attributes that on the Internet are hard to present. To sum up, nowadays customers are getting more and more narcissistic and companies use this trend in marketing campaigns bringing them to online communities and offering products and services that aim at emphasizing originality and unique style.

In times where customers socialize online and express themselves in the cyberspace, companies need to understand that virtual communities posses huge power of influencing potential customers. The advent of Web 2.0 disseminated blogs as a tool of expressing lifestyles and opinions. From private diaries, they've evaluated into powerful tools and some event changed into multimillion businesses.

Nowadays bloggers perceived as content creators are digital influencers, very proficient at connecting with users through social media (Uzunoglu and Kip, 2014). Borah (2015) also proved that blog readers find these sites more credible than the mainstream media that present their potential influence on customers.

The everyday practices of online reality, such as opinions, reviews, comments, likes, shares, following, and followers, have become crucial for understanding nowadays customers. But where people may express their thoughts freely, almost without any restrictions, another phenomenon appears haters. Cohen-Almagor (2014) and Oksanen (et al., 2014) suggested that online reality plays a crucial role in spreading hate and translating speech into action as well as making hateful material more and more visible for broad audience. Hating takes a form of offensive, insulting, intimidating, threatening, harassing comments and statements and incites to violence, aggression, hatred, and discrimination (Erjavec and Kovačič, 2012).

Hating is a phenomenon that needs to be understand by companies that aim for starting online activities. They need to learn how to discriminate between hateful comments and constructive critic and how to react in cyberspace to earn credibility and do not lose customers. 


\section{$3 \quad$ Methodology and construction of the study}

The conducted study tended toward examining representatives of generations $\mathrm{Y}$ and $\mathrm{Z}$ and their online activities that may influence customers' behaviors.

To reach this aim, a questionnaire with the high level of standardization was prepared. Standardization refers to the fact that all respondents were asked the same questions in the same order. Questions were predominantly closed ones, in which respondent had to select answers from a list of options prepared by the author. In the case of open questions, respondent could answer without any guidance.

Considering the method of filling questionnaires, two basic techniques in quantitative researches may be distinguished: questionnaire that respondent fill independently and an interview questionnaire in which questions are asked and written down by the interviewer. For the purpose of this study, the first method was chosen.

The questionnaire was anonymous. It was designed to investigate several features described in previous sections:

- narcissistic tendencies,
- hating activities,

- socializing online,

- blogging,

- immersion into virtual reality,

- shopping online.

To examine the above aspects, some questions centered on daily activities and their frequency, so they referred to objective facts. Other questions pointed at recognizing attitudes and beliefs of respondents about themselves as they may be an important factors influencing customers' decisions.

The sample amounted to 405 young people from both $\mathrm{Y}$ and $\mathrm{Z}$ generations.

\section{$4 \quad$ Findings}

First group of questions was dedicated to the Internet usage pattern. It is said that generations $\mathrm{Y}$ and $\mathrm{Z}$ are always online, young people are even named as "generation AO" for "always-on" (Anderson, 2012). Results seem to prove this fact as 368 out of 405 respondents declared that they use the Internet constantly or several times a day. Detailed statistics are presented in Fig. 2.

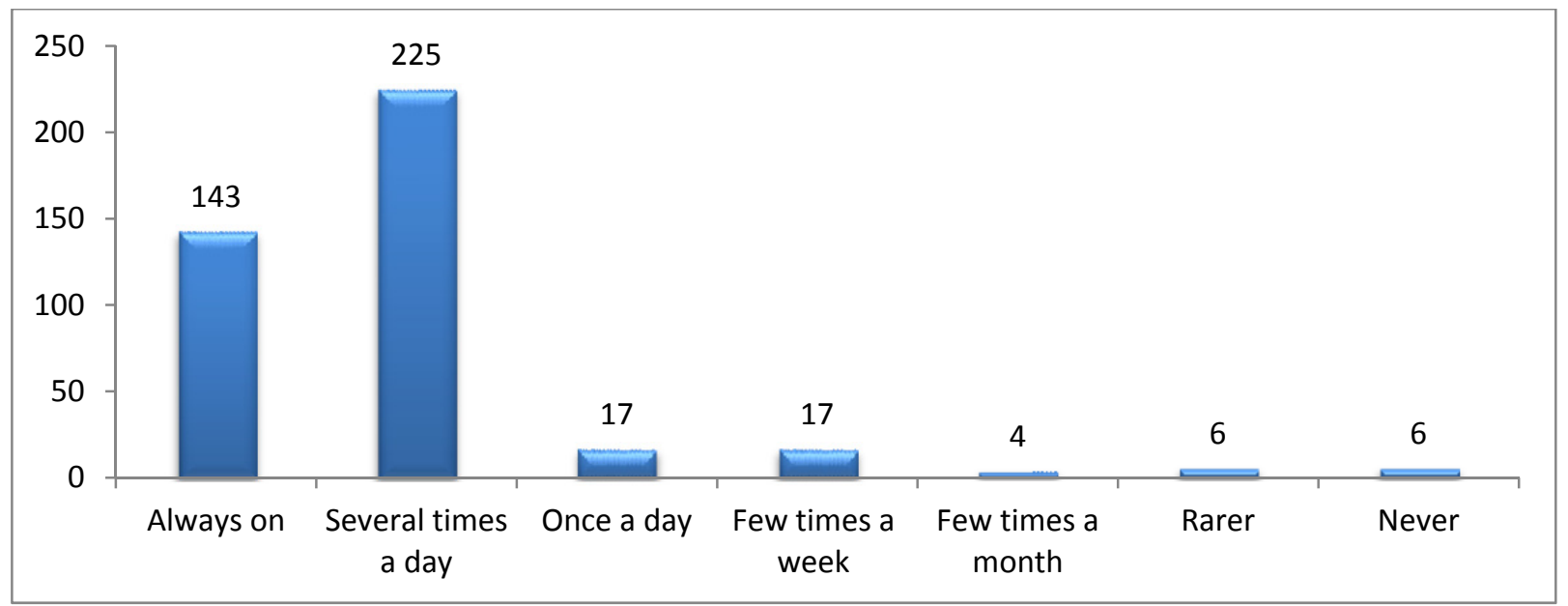

Figure 2. Frequency of the Internet usage among respondents (source: own elaboration)

About 399 respondents claim to use social media services with Facebook being the most popular choice as presented in Fig. 3. Simultaneously, they declared possessing one active account on these ser- vices (72 answers), two or three (206 answers), four or five (96 answers), and 19 respondents have more than six accounts they regularly use. 


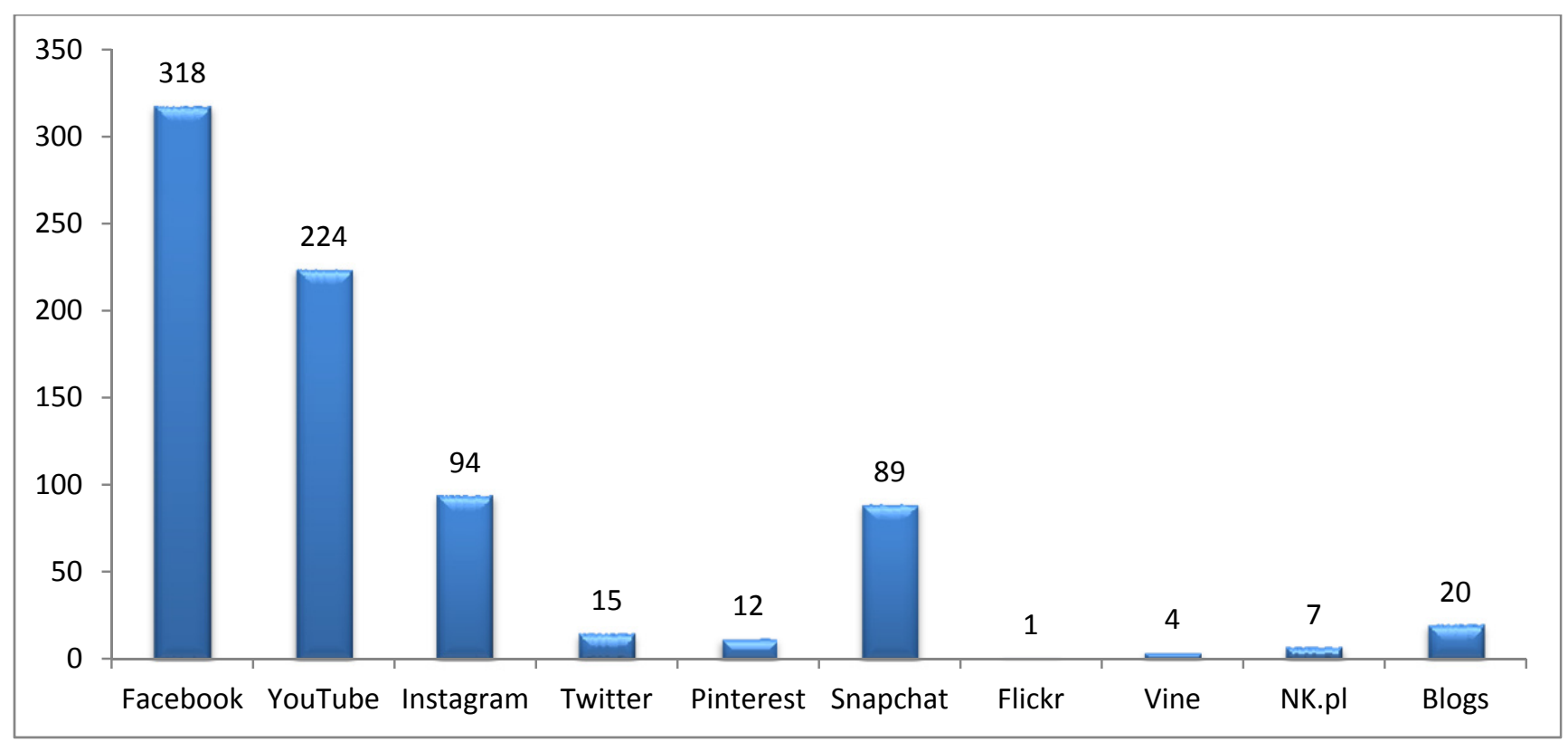

Figure 3. Social media services used by the respondents (source: own elaboration)

Socializing seems to be one of the most tempting aspects of online environment as 323 respondents perceive content published by their friends or communities they are members of as the most interesting. In comparison, only 57 persons feel that content published by the companies is much more alluring and 33 chose to follow news published by celebrities.

Also 353 respondents admit that the most important reason of being online is to stay in touch with friends and their close ones. The average number of Facebook friends amounts to 453 .

Table 1. Respondents declarations about evincing narcissistic behaviors online (source: own elaboration)

\begin{tabular}{|c|c|c|c|c|c|}
\hline \multirow{5}{*}{$\begin{array}{c}\text { "I retouch my published } \\
\text { photos" }\end{array}$} & Regularly & 33 & \multirow{5}{*}{ "I lie about myself online" } & Regularly & 5 \\
\hline & Sometimes & 78 & & Sometimes & 11 \\
\hline & Occasionally & 106 & & Occasionally & 29 \\
\hline & Never & 116 & & Never & 222 \\
\hline & $\begin{array}{l}\text { I don't pub- } \\
\text { lish }\end{array}$ & 62 & & $\begin{array}{l}\text { I don't write } \\
\text { about myself }\end{array}$ & 131 \\
\hline \multirow{3}{*}{ "My online life" } & Is marginal & 113 & $\begin{array}{l}\text { Is an important part of my } \\
\text { personality }\end{array}$ & 28 & \\
\hline & Makes life easier & 255 & $\begin{array}{l}\text { Is more important than real } \\
\text { life }\end{array}$ & 5 & \\
\hline & Influence who I am & 33 & & & \\
\hline
\end{tabular}


As stated in Section 2.2, Millenials and generation Z's representatives are recognized as digital narcissists. Table 1 presents respondents' answers that refers to narcissistic behaviors online.

As seen in Table 1, 217 respondents retouch published photos of themselves, to appear more attractive on the Internet, 116 declare not doing this, and 62 not publishing at all. Still, they are trying to remain honest about posted information as only 45 persons declared to lie about themselves.

They also perceive the Internet most commonly as the useful tool (255 answers) or treat their online activities as a marginal part of everyday life (113). Only $8 \%$ feels that cyberspace may influence their personality, $6.91 \%$ feels that it is actually happening, and $1.23 \%$ realizes that online reality is more important than real life.

Above statistics seem to be quite positive about low level of narcissistic tendencies and immersion into cyberspace among respondents. Still, some attempts in creating appealing online personality may be noticed.

Young people are also usually generation C's representatives, which means that they may also become content creators and opinion leaders. In the conducted study, 18 out of 405 respondents (4.44\%) run a blog and $46(11.35 \%)$ publish regularly some content on specific topic. Eighty-two declare commenting regularly and 26 tag online content.

While expressing their opinions, respondents show diversified attitudes as presented in Fig. 4.

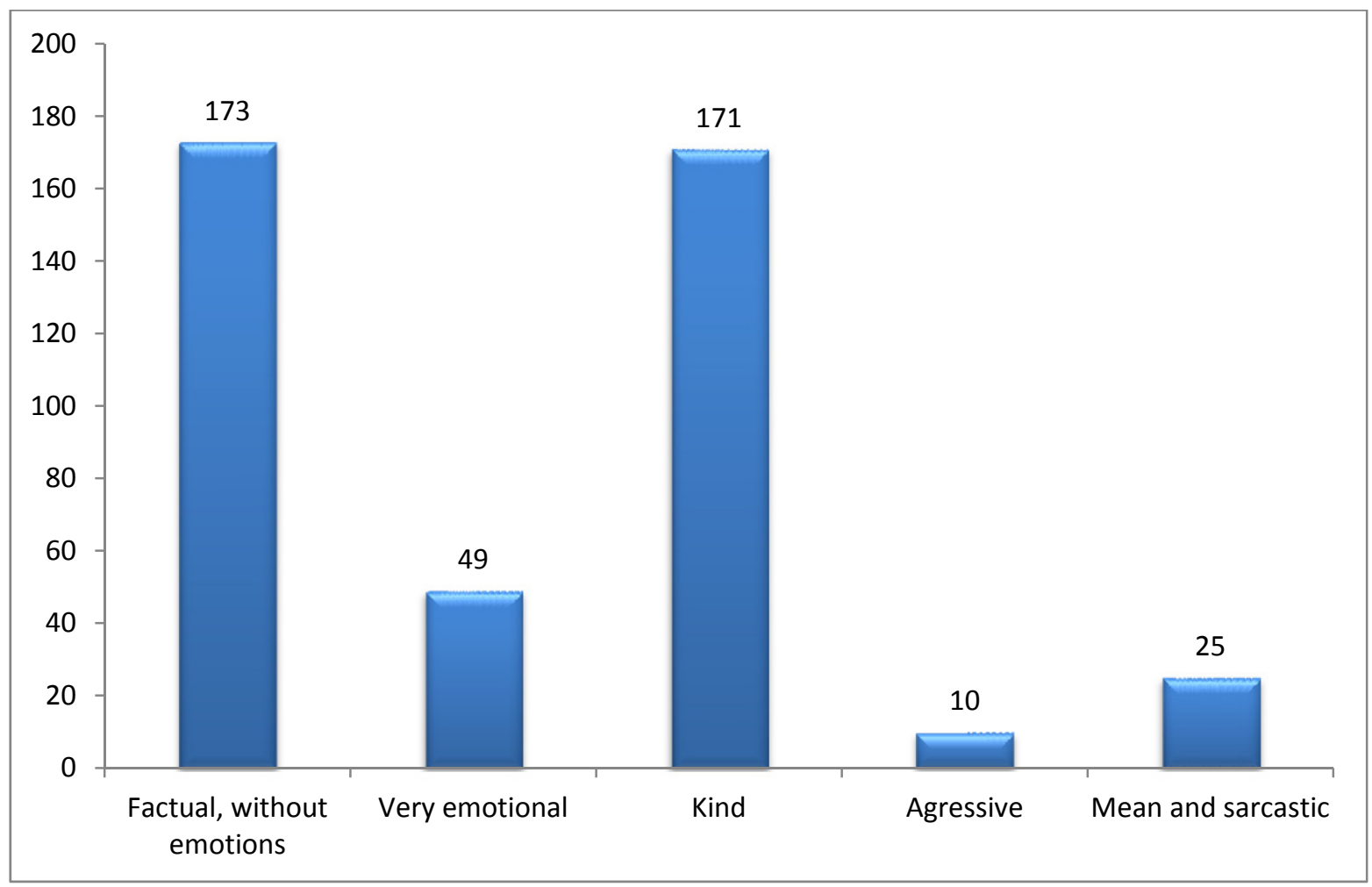

Figure 4. Character of published content (source: own elaboration)

As opinion leaders, young people on the Internet may also publish hateful, even unjustified, content.
Respondents' behaviors connected with hating are presented in Table 2. 
Table 2. Hateful and aggressive online behaviors among respondents (source: own elaboration)

\begin{tabular}{|c|c|c|c|}
\hline Statement & $\begin{array}{c}\text { Number } \\
\text { of positive responses }\end{array}$ & Statement & $\begin{array}{c}\text { Number } \\
\text { of positive responses }\end{array}$ \\
\hline "I am hater" & $49(12.09 \%)$ & "I'm aggressive" & $9(2.22 \%)$ \\
\hline "I quarrel" & $60(14.81 \%)$ & "I'm prone to abuses" & $5(1.23 \%)$ \\
\hline "I lie" & $24(5.92 \%)$ & "I have less inhibitions" & $41(10.12 \%)$ \\
\hline
\end{tabular}

As future customers, young people are getting theirs' feet wet in online shopping as 173 of them declare to buy products on the Internet. About 352 respondents $(88 \%)$ claim that they procrastinate online, and $72(18 \%)$ lose a sense of time while performing online shopping.

\section{Conclusions}

Millenials and generation Z's representatives seem to be more complex as customers than previous generations, because of the fact that online reality has become an inherent part of their lives.

Being online and possessing a social media marketing strategies is obvious for nowadays companies. Present on Facebook, Instagram, YouTube, Twitter, and other social media services; running company's blogs; and interacting with online communities are becoming quite fluent in cyberspace reality.

Yet, companies have to realize the complex nature of young people surfing over the Internet. They want to be active individuals, popular and adored by online communities, with bunch of followers and thousands of likes. They comment, share, and become opinion leaders, sometimes very influential ones.

If they like a selected brand, these young customers may spread a good word about it widely on the cyberspace and make it desirable by others. At the same time, they may evince aggressive and hateful behaviors, publish sarcastic, mean comments, or even lie. That type of activities along with wide social network and high level of influence on it may lead to creation of undesirable image for a brand they decide to write about.
The paper aimed at presenting social and psychological approaches to this type of customer. First, generations $\mathrm{Y}, \mathrm{Z}$, and $\mathrm{C}$ and their internet usage patterns were presented. Then, the most important psychological aspects, including socializing online, narcissistic tendencies, hating activities, blogging, immersion into virtual reality, and shopping online, were discussed. Also a study has been conducted to investigate these behaviors on the sample of 405 young people.

Among study's limitations, following can be mentioned:

- first, the research is unrepresentative statistically as the probe was quite small; that is why, the results can't be generalized for the whole population,

- second, because of the fact that it was aiming at investigating various psychological aspects, including attitudes and beliefs, the results present a subjective respondents opinions.

In the future works, the author of this paper would like to concentrate on selected features (i.e., narcissistic tendencies and hating activities) of this study and examine them more closely.

\section{$6 \quad$ References}

[1] Anderson, D., 2012. Elon Studies the Future of "Generation Always-On". [online] Available at: <http://www.elon.edu/e-net/Article/59585> [Accessed 25 November 2016].

[2] Borah, P., 2015. Blog Credibility: Examining the Influence of Author Information and Blog Reach. Atlantic Journal of Communication, 23, pp.298-313. 
[3] Cohen-Almagor, R., 2014. Countering Hate on the Internet. Annual Review of Law and Ethics, 22, pp.431-443.

[4] Dabija, D-C., Babut, R. and Lugojan, I.M., 2016. Information Search Behaviour Based on Social Media. A Generational Perspective in Romania. Conference Proceedings: Marketing from Information to Decision, At Cluj-Napoca, Romania, 9.

[5] Dejnaka, A., 2013. Proces podejmowania decyzji zakupowych przez e-konsumentów w kontekście mediów spolecznościowych. Warszawa: CeDeWu.

[6] Dhanapal, S., Vashu D. and Subramaniam, T., 2015. Perceptions on the Challenges of Online Purchasing: A Study from "Baby Boomers", Generation "X" and Generation "Y" Point of Views. Contaduría y Administración, 60, pp.107-132.

[7] Dooley, J., Jones, S.C. and Iverson, D., 2014. Using Web 2.0 for Health Promotion and Social Marketing Efforts: Lessons Learned From Web 2.0 Experts. Health Marketing Quarterly, 31(2), pp.178-196.

[8] Erjavec, K. and Kovačič, M.P., 2012. "You Don't Understand, This is a New War!" Analysis of Hate Speech in News Web Sites' Comments. Mass Communication and Society, 15(6), pp.899-920.

[9] Escoda, A.P., Zubizarreta, A.C. and Higado, M.F., 2016. Digital Skills in Z Generation: Key Questions for a Curricular Introduction in Primary School. Comunicar, 49(4), pp.71-79.

[10] Facebook IQ, 2016. Modern Loyalty: Love in a Time of Infinite Choice. [online] Available at: $<$ http://insights.fb.com/2016/11/01/modernloyalty-love-in-a-time-of-infinite-choice/> [Accessed 18 November 2016].

[11] Ferguson, D.A. and Geer, C.F., 2016. Reaching a Moving Target: How Local TV Stations are Using Digital Tools to Connect With Generation C. The International Journal on Media Management, 18(3), pp.1-20.

[12] Fletcher, K-A., 2016. Social Media Engagement: Reshaping the Consumption Patterns of Generation Y Caribbean and Latin American Consum- ers. In: A. Gbadamosi, ed., 2016. Handbook of Research on Consumerism and Buying Behavior in Developing Nations, Hershey: IGI Global, pp.218-238.

[13] Greydanus, D.E. and Greydanus, M.M., 2012. Internet Use, Misuse, and Addiction in Adolescents: Current Issues and Challenges. International Journal of adolescent medicine and health, 24(4), pp.283-289.

[14] Hassan, S.T. and Shailesh, K., 2016. Emerging Trends in Instant Messaging Usage Among the Generation y for Enhancing Connectivity. International Journal of Applied Business and Economic Research, 14(7), pp.5097-5104.

[15] Hulten, B., 2015. Sensory Marketing: Theoretical And Empirical Grounds, New York: Routledge.

[16] Jabłońska, M.R. and Billewicz, K., 2016. Pokolenie przełomu w Web 2.0 (Web 2.0 Break through Generation). Acta Universitatis Lodziensis. Folia Sociologica, 56, pp.83-97.

[17] Kaplan, B., 2015. Marketing Strategies For The Generation "C" Consumer Behavior: An Overview For The GSM Market in Turkey. In: U., Akkücük, ed. 2015. Developing Sustainable Value in Economics, Finance, and Marketing. Hershey: IGI Global.

[18] Lai, I.K.W. and Liang, D., 2009. The Sociodemographic Profile of Generation Y Online Shoppers in Taiwan. International Journal of Electronic Customer Relationship Management, 3(2), pp.132-148.

[19] Lee, A. and Cook, P.S., 2014. The Conditions of Exposure And Immediacy: Internet Surveillance and Generation Y. Journal of Sociology, 51(3), pp.674-688.

[20] Leibtag, A., 2013. The Digital Crown. Winning at Content on the Web., Waltham: Elsevier.

[21] Lim, Y.J., Osman, A., Manaf, A.H.A. and Abdullah, S., 2015. The Mediating Effect of Consumers' Purchase Intention: A Perspective of Online Shopping Behavior among Generation Y. Journal of Marketing and Consumer Research, 18, pp.101-112. 
[22] Lim, Y.S., Heng, P.Ch., Ng, T.H. and Cheah, Ch.S., 2016. Customers' Online Website Satisfaction in Online Apparel Purchase: A Study of Generation Y in Malaysia. Asia Pacific Management Review, 21(2), pp.74-78.

[23] Lissitsa, S. and Kol, O., 2016. Generation X vs. Generation Y - A Decade of Online Shopping. Journal of Retailing and Consumer Services, 31, pp.304-312.

[24] Makhitha, K.M., 2014. Factors Influencing Generations Y students' Attitude towards Online Shopping. Mediterranean Journal of Social Sciences, 5(21), pp.39-50.

[25] Mitchell, V., Petrovici, D., Schlegelmilch, B.B. and Szöcs I. (2015). The Influence of Parents Versus Peers on Generation Y Internet Ethical Attitudes. Electronic Commerce Research and Applications, 14(2), pp. 95-103.

[26] Muda, M., Mohd, R. and Hassan, S., 2016. Online Purchase Behavior of Generation $\mathrm{Y}$ in Malaysia. Procedia Economics and Finance, 37, pp.292-298.

[27] Nielsen Report, 2014. Millennials: Technology = Social Connection. [online] Available at: $<$ http://www.nielsen.com/us/en/insights/news/20 14/millennials-technology-social-connection .html $>$ [Accessed 10 November 2016].

[28] Nowak, A. and Krejtz, K., 2006. Internet z perspektywy nauk społecznych (Internet from the Perspective of Social Sciences). In: D. Batorski, M. Marody and A. Nowak, eds., 2006. Spoleczna przestrzeń internetu (Internet Social Space).Warsaw: Academica, pp.5-19.

[29] Okansen, A., Hawdon, J., Holkeri, E., Näsi, M. and Räsänen, P., 2014. Exposure to Online Hate among Young Social Media Users. In: M.N. Warehime, ed., 2014. Soul of Society: A Focus on the Lives of Children \& Youth (Sociological Studies of Children and Youth, Volume 18), Oklahoma City: Emerald Group Publishing Limited.

[30] O'Reilly, T., 2005. What Is Web 2.0. Design Patterns and Business Models for the Next Generation of Software. [online] Available at: $<$ http://www.oreilly.com/pub/a/web2/archive/ what-is-web-20.html?page $=1>\quad$ Accessed 03 November 2016].
[31] Ozkan, M. and Solmaz, B., 2015. Mobile Addiction Of Generation $\mathrm{Z}$ And Its Effects On Their Social Lifes (An application among university students in the 18-23 age group). Procedia Social and Behavioral Sciences of 6th World Conference On Psychology, Counseling And Guidance (WCPCG-2015), 205, pp.92-98.

[32] Prensky, M., 2001. Digital Natives, Digital Immigrants. On the Horizon, 9, pp.1-6.

[33] Qvortrup, L., 2003. The Hypercomplex Society, New York: Peter Lang Publishers.

[34] Rahman, S.M., 2015. Optimizing Digital Marketing for Generation Y: An Investigation of Developing Online Market in Bangladesh. International Business Research, 8(8), pp.150-163.

[35] Rakshikar, N.N., 2015. Application of Web 2.0 in Academic Libraries: A Study of College Libraries in Mumbai. International Journal of Advanced Research, 3(7), pp.768-777.

[36] Seo, J-I., 2016. Internet Shopping Behaviors of Generation Y African-American Based on Apparel Production Involvement. International Business Research, 9(9), pp.64-77.

[37] Shin, S-J.H., Fowler D.C. and Lee, J., 2013. Teens and College Students' Purchasing Decision Factors of Denim Jeans In the United States. Fashion \& Textile Research Journal, 15(6), pp.971-976.

[38] Simanjuntak, M. and Musyifah, I., 2016. Online Shopping Behavior on Generation Y in Indonesia. Global Business Finance Review, 21(1), pp.33-45.

[39] Smutny, Z., Janoščík, V., and Čermák, R., 2016. Generation $\mathrm{Y}$ and Internet Privacy: Implication for Commercialization of Social Networking Services. In: V. Benson, R. Tuninga, G. Saridakis, eds. 2016. Analyzing the Strategic Role of Social Networking in Firm Growth and Productivity, Edition: Advances in E-Business Research, Hershey: IGI Global, pp.95-119.

[40] Stein, J., 2013. Millennials: The Me Me Me Generation. Time, May 20, 2013. [online] Available at: $<$ http://time.com/247/millennials-theme-me-me-generation/> [Accessed 18 November 2016]. 
[41] Suler, J., 2004. The Online Disinhibition Effect. Cyber Psychology \& Behavior, 7(3), pp.321326.

[42] Tennant, B., Stellefson, M., Dodd, V., Chaney, B., Chaney, D., Paige, S. and Alber, J., 2015. Information Seeking Behaviours Among Baby Boomers and Older Adults. Journal of Medical internet Research, 17(3), p.e70.

[43] Uzunoglu, E. and Kip, S.M., 2014. Brand Communication through Digital Influencers: Lever- aging Blogger Engagement. International Journal of Information Management, 34(5), pp.592602.

[44] Zhitomirsky-Geffet, M. and Blau, M., 2016. Cross-generational Analysis of Predictive Factors of Addictive Behavior in Smartphone Usage. Computers In Human Behavior, 64, pp.682693. 